УДК: 657.6:001.895

JEL Classification: L 26

I. М. МАЙОРОВА,

доктор економічних наук,

професор кафедри технологій міжнародних перевезень і логістики, ДВНЗ «Приазовський державний технічний університет»

\title{
Облік і аудит ресурсозберігаючих інновацій на сучасних промислових підприємствах
}

В статті подано авторський погляд на організацію обліку і аудиту ресурсозберігаючих інновацій на промислових підприсмствах. Облік ресурсозберігаючих інновацій проводиться як облік нематеріальних активів або об 'єктів інтелектуальной власності. Подано авторський підхід до організачії аудиту з урахуванням відповідності ресурсозберігаючих інновацій тесту М. Портера з таких пунктів: зміни в технологіях дозволяють знизити витрати, але при цьому технологічне лідерство підприємства має сталу позицію; завдяки ресурсозберігаючим змінам змінюється і напрям дій ключових факторів витрат; ресурсозберігаючі зміни сприяють покраценню структури підприсмства холдингу.

Ключові слова: ресурсозберігаючі інновачій, бухгалтерський облік, нематеріальні активи, фінансово-господарська діяльність, витрати, поліуретанова піна, кореспонденція рахунків.

Постанова проблем та ї̈ зв'язок із важливими науковими чи практичними завданнями. Ресурсозбереження і енергозбереження - це найважливіші складові проблеми «енергетичної безпеки» всіх країн світу. Ресурсозбереження важливо не саме по собі, а в тому сенсі, в якому воно сприяє отриманню конкурентних переваг і покрашенню ситуації на підприємстві. Не всі заходи ресурсозбереження позитивно впливають на роботу підприємства, деякі мають негативний вплив на конкурентну позицію і на прибуток підприємства взагалі. Відомий фахівець 3 теорії конкурентоспроможності Майкл Портер вказував, що серед керівників сучасних промислових підприємств існує безліч різних інтерпретацін̆ поняття «позиція підприємства за витратами» відносно конкурентів і ресурсозберігаючих інновацій. Дослідження витрат зазвичай торкаються проблематики виробничих витрат і не охоплюють витрати на інші види діяльності: маркетинг, сервіс, інфраструктуре, транспортування і складування та інші. Керівництво підприємств найчастіше обмежується спрощеним порівнянням власних витрат на оплату праці і сировину з витратами конкурентів [1, с. 105-106].

Причини такого спрощеного підходу слід шукати у відсутності системності в аналізі витрат на ресурсозберігаючі інновації та їх бухгалтерсыкого обліку. Багато досліджень витрат і ресурсозберігаючих інновацій присвячені досить вузыким питанням у межах цієї галузі, а їх результати і висновки мають короткочасну цінність. Сучаспі системи бухгалтерського обліку потребують більш чіткої і жорсткої класифікації витрат і ресурсозберігаючих інновацій відповідно до структури бази даних в таких категоріях як, наприклад, витрати на основну і допоміжну роботу, накладні витрати. У практиці бухгалтерського обліку використовується штучний поділ витрат на робочу силу, сировину, накладпі витрати, які включаться до одного і того ж самого виду діяльності. Вищезазначене підвищує актуальпість аналізу підходів до оргапізації обліку і аудиту ресурсозберігаючих інновацій на промислових підприємствах.

Аналіз останпіх досліджень і иублікацій. Дослідженню питань управління процесами ресурсозбереження на різноманітних рівнях розвитку промисловості присвячено наукові праці О. Амоша, С. Аптекарь, М. Белопольського, О. Біловодської, Ю. Воробйова, Б. Гаврилішина, Р. Дафта, О. Зборовсыкої, С. Ілляшенкко, В. Кудінової, Е. Левінса, Т. Логутової, С. Мочерного, Ж. Піскова, С. Соколова, І. Сотникова, Дж. Стівенсона, О. Устенко, Р. Факхутдинова та інших. Питання обліку, аналізу та впровадження ресурозберігаючих інновацій розглядалися в наукових працях С. Крікавсыкого, М. Бело-

(C) I. М. Майорова, 2017 
польського, Г. Бессонової, С. Бессонової, О. Польторацької та інших. У наукових працях вищезгаданих авторів підкреслюється, що прюритетними напрямами промислової політики всіх країн світу є енергозбереження, енергоефективність, екологічність. В багатьох законодавчих актах як національного та і міжнародного права зазначено, що від правильності проведення енергетичної і ресурсозберігаючої технологій залежить безпека держави, захишеність життєво важливих інтересів і запобігання внутрішнім і зовнішнім загрозам.

Мета статті: дослідити організацію бухгалтерсыкого обліку і аудиту ресурсозберігаючих технологій на промислових підприємствах.

Виклад основного матеріалу з повннм обгрунтуванням отрнманнх наукових результатів. Ресурсозбереження - це процес послідовної і комплексної реалізації організаційних, економічних і технічних заходів, спрямованих на забезпечення економії та раціонального використання матеріально-сировинних ресурсів у всіх галузях народного господарства [3, с. 208]. Основні напрями ресурсозбереження: зменшення обсягів видобутку матеріальних ресурсів і заміна їх раціональними видами; збільшення корисного виходу матеріальних ресурсів; зниження норм витрат матеріальних ресурсів на одиницю продукціі; комплексне використання матеріальних ресурсів у виробництві; використання відходів, вторинних ресурсів; поліишення якості та збільшення тривалості експлуатації матеріальних ресурсів. Найсуттєвішого результату ресурсозбереження досягають за умови, коли процес ресурсозаощадження охоплює всі стадії життєвого циклу ресурсу. Найбільш поширеними методами ресурсозбереження є такі: впровадження прогресивної ресурсозберігаючої техніки і технології; вдосконалення конструкції продукції; використання нових видів сировини та матеріалів; розроблення нових видів ресурсів; організація технологічного використання відходів; застосування раціональних пакувальних матеріалів і конструкцій упаковки; вдосконалення технології складського зберігання і створення умов для зберігання матеріальних ресурсів; впровадження раціональних видів транспортування, скорочення відстані транспортування матеріальних ресурсів. Основним джерелом фінансування інноваційної діяльності 3 енерго- та ресурсозбереження є власні кошти промислових нідприємств.

Аналіз різних нідходів до ресурсозбереження, викладений у другій главі монографії [4, с. 45-145], дозволяє визначити та узагальнити ключові напрямки розвитку сучасної комплексної системи ресурсозбереження на вітчизняних промислових підприємствах, яким притаманні: зміиа форм власності та створення вертикальноінтегрованих компапій); використання у виробництві матеріалів із поліишеними якостями; впровадження інноваційних економічних видів паливно-енергетичних ресурсів; залучення енергетичного менеджменту у розроблення довгострокових програм енергозбереження; використання міжнародних стандартів фінансової звітності, що дало можливість знайти і залучити внутрішні резерви економії виробничих ресурсів.

Використання поняття «ресурсозбереження» у науковій літературі $є$ відносно новим. Раніше в економічній теорії та фінансово-господарській діяльності активно вживалися такі поняття як «економія ресурсів», «режим економії» або «ефективне використання ресурсів». На сьогоднішній день усі наведені вище терміни акумульовані у поняття «ресурсозбереження», яке $\epsilon$ досить багатогранним. У науковій праці [5] стверджується, «що сучасна цивілізація досягла рівня розвитку, на якому зростання виробництва фактично в усіх галузях господарства здатне здійснюватися в умовах прогресуючої економіки без залучення додаткових ресурсів та енергії».

За даними авторів монографії [2, с. 46], рівень енергоємності ВВП Україии складає 0,41 кг нафтового еквіваленту на 1 дол. США, а середній світовий показник $-0,2$ кг нафтового еквіваленту на 1 дол. США. Тобто щоб виробити будь-яку продукцію, Україна витрачаєу 4 рази більше енергії і ресурсів, ніж країни Свропи, і вдвічі більше, ніж Російська Федерація. Україна відстає від показників енергоефективності економіки Чехії вдвічі, Польщі - у 2,6 раза, Данії - у 4,5 раза. Щорічні витрати України від неефективного енерго- та ресурсоспоживання у комунальному господарстві та промисловості складають 15-17 млрд. дол.

Майкл Портер пропонує тест для визначення тих напрямів ресурсозберігаючих технологічних змін, впровадження яких матиме максимальний позитивний ефект для роботи компанії: 
1. Змгіни в технологіях дозволяють знизити витрати, але при цьому технологічне лідерство підприємства має сталу позицію.

2. Завдяки ресурсозберігаючим змінам змінюсться і напрям дій ключових факторів витрат: вони позитивно впливають на ефективну роботу компапії.

3. Ресурсозберігаючі зміни сприяють покрашенню структури підприємства або холдингу [1, с. 252-254].

Оскільки українські гідприємства змушегі працювати в кризових умовах, не мають достатньо коштів для великих капітальних інвестицій у нові прогресивпі екологічпі та енергозберігаючі технології, ресурсозбереження є одним із головних факторів підвищення їх конкурентоспроможності, зниження собівартості продукції і послуг i вивільнення фінансових коштів для подальшого технологічного удосконалення процесу виробништва.

В Україпі $\epsilon$ всі потенцін̆пі можливості для впровадження ресурсозберігаючих технологій, в тому числі для енергозбереження. Прикладом може служити підприємство «Дон-трейд», яке за власною технологією виробляє пінополіуретановий герметик PENADO в аерозольпій упаковці [2, с. 16-18]. Це готова до застосування однокомпонентна піна, яка твердіє під впливом вологи повітря, утворюючи комірчасту напівжорстку пластмасу з високими теплоізоляційними властивостям. Застосування поліуретанової піни дозволяє:

- понизити тепловіддачу на 54\%;

- зберегти тепло взимку і створити приємний прохолодний мікроклімат влітку;

- різко знизити витрати енергії на опалювання або охолодження різних типів приміщень;

- підвищити термін праці оброблених піною трубопроводів у 3-4 рази, досягти економії газу на $50 \%$ і більше завдяки зниженню тепловтрат;

- знизити корозію зовпішньої стінки сталевої труби, поліпшити їі ремонтоздатність і можливість багатократного використання.

Ефективна ізоляція труб - це один зі шляхів економії теплової енергії в умовах енергетичної кризи. Жорсткий пінополіуретан (ППУ) як теплоізоляційний матеріал наразі не має альтернативи. Він мас високий коефіціснт ізоляції і низький коефіціснт теплопровідності, високу міцність і теплостійкість форми, відрізняється чудовою адгезією до металів. При температурі теплоносія $120^{\circ} \mathrm{C}$ довговічпість його експлуатації складає 25-30 років, причому одночасно підвищується і термін служби металевих труб завдяки гідроізоляцийним властивостям цього матеріалу. Розрахунки фахівців показали, що застосування 1 кг ППУ за рік дозволяє заощадити в середньому 24,37 грн [2, с. 18].

Ефективна ізоляція труб пінополіуретаном покрашує можливості для централізованого теплопостачання від теплоцентралей в крупних житлових районах 3 високою концентрацією населення, що дозволяє зекономити більше $20 \%$ енергії у порівнянпі з індивідуальними топковими прибудовами, а також зменшити хімічне і термічне навантаження на навколишнє середовище. Крім того, відпрацьований ППУ легко утилізувати термічним засобом на відміну від мінеральної вати.

Для потреб бухгалтерського обліку ресурсозберігаючі інновації включаються до інтелектуальної власності підприємства, тобто до нематеріальних активів. Оргапізація обліку ресурсозберігаючих інновацій і технологій промислових підприємств зводиться до оргапізації обліку операцій зі створення та придбання об єктів патентного права і інтелекту альної власності. Авторський підхід до проведення обліку і аудиту ресурсозберігаючих інновацій промислових підприємств викладено на рисунку.

Якщо ресурсозберігаюча інновація отримується на промисловому підприємстві в результаті обміну або є його власною розробкою, первинна вартість отриманих у такий спосіб нематеріальних активів дорівнює залишковій вартості переданого об'єкта. Вона визначається як різниця між первиною вартістю і сумою нарахованого зносу. Якшо залишкова вартість переданого об'єкта перевищує його справедливу вартість, тоді його первинна вартість дорівнює його справедливій вартості. Первинна вартість безоплатно отриманих нематеріальних активів також дорівнює справедливій вартості на дату їх отримання.

Всі витрати на придбання та створення об'єктів патентного права у разі їх використання підприємством в якості активів урегульовано нормами ПСБО 8 
«Нематеріальні активи» [6] і ПСБО 27 «Необоротні активи, утримувані для продажу та припинення діяльності» [7]. Ці витрати як канітальні інвестиції в нематеріальні активи обліковуються на субрахунку 154 «Придбання (створення) нематеріальних активів». А після їх завершення та введення об єкта патентного права у господарський оборот він оцінюється за первісною вартістю, що складається 3 прямих витрат на його створення та відображається як нематеріальний актив на субрахунку 124 «Права на об єкти промислової власності» для внутрішнього використання або 286 «Необоротні активи та групи вибуття, утримувані для продажу» для реалізації на сторону.

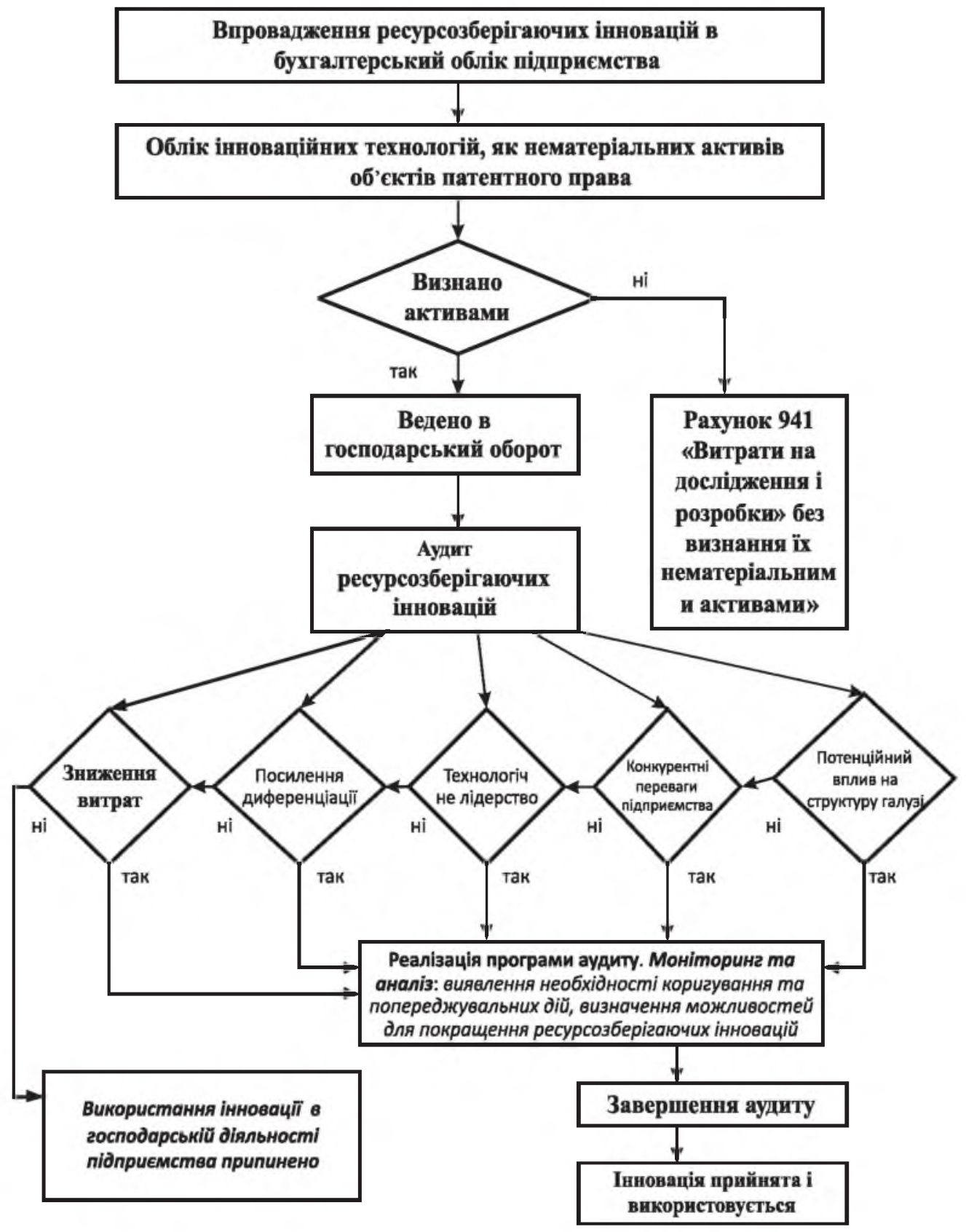

Рис. Модель проведения обліку і аудиту ресурсозберіганчнх інновацій промислових пндприємств

Джерело: розроблено автором 
У разі, якщо витрати на створені об' єкти патентного права (рисунок) не визначаються як активи і не отримують відображення в обліку як об'єкти права інтелектуальної власності, на які видано патенти, вони відносяться на рахунок 941 «Витрати на дослідження і розробки» без можливості їх визначення у майбутньому нематеріальним активом. Така вимога закріплена нормами пункту 8 ПСБО «Нематеріальні активи», що $\epsilon$ логічним продовженням норм пункту 7 ПСБО, який визначас умови відображення в балансі таких активів [7].

В теорії обліку та аудиту існують три класичні нідходи до оцінки нематеріальних активів: витратний підхід, порівняльний підхід, прибутковий нідхід. Витратний нідхід використовують при оцінці вартості нематеріальних активів в тому випадку, якщо неможливо знайти аналоги, а прогнозований прибуток не $є$ стабільним. Порівняльний нідхід оснований на принцині ефективного ринку, на якому інвестори купують i продають активи аналогічного типу, ухвалюючи при цьому незалежні індивідуальні рішення. Прибутковий підхід оснований на розрахунку економічних вигід, пов'язаних 3 отриманням прибутку від нематеріальних активів, які не відображені на балансі нідприємства і забезпечують прибуток на активи або власний капітал вище середнього рівня.

3 метою достовірної оцінки та визнання в обліку ресурсозберігаючих інновацій авторами монографії [2, с. 30] пропонується здійснення їх позабалансового обліку як списаних потенційних нематеріальних активів. Для обліку не визнаних нематеріальних активів використовують рахунок 07 «Списані активи», зміст і назву якого пропонується змінити на «Списані активи та потенційні нематеріальні активи» та відкрити субрахунок 073 «Списані потенційні нематеріальні активи». На цьому субрахунку пропонується здійснювати облік прав інтелекту альної власності за вартістю прямих фактично понесених витрат на їх створення та щорічне нідтримання патентоспроможності. Потенційні нематеріальні активи остаточно списуються із субрахунку 073 «Списані потенщійні нематеріальні активи» після вирішення питання щодо умов відображення таких об єктів у балансі як відновлених. Одночасно зі зменшенням сум списаних потенційних нематеріальних активів пропонується здійснювати запис за дебетом рахунків 12 «Нематеріальні активи» або 286 «Необоротні активи та групи вибуття, утримувані для продажу» і кредитом рахунку 42 «Додатковий капітал», з подальшим їх віднесенням (у сумі амортизації або повністю для нематеріальних активів, що не амортизуються) на субрахунок 74 «1нші доходи». Для цього нами пропонується введення нових субрахунків до вказаних рахунків, відповідно: 426 «Відновлені раніше списані потенційні нематеріальні активи» та 743 «Доход від відновлення раніше списаних потенцін̆них нематеріальних активів». Оцінка та визнання в обліку відновлених раніше списаних потенційних нематеріальних активів має здійснюватися за вартістю раніше списаних прямих витрат на їх створення та нідтримання патентоспроможності, скоригованою на суми амортизації та переоцінки, які було б визнано за період їх позабалансового утримання; сума коригування має включатися до інших витрат (доходів) звітного періоду в кореспонденції з рахунком обліку таких активів [2, с. 31].

Витрати на придбання нематеріальних активів накопичуються на рахунку 15 «Канітальні інвестиції», субрахунок 154 «Придбання (створення) нематеріальних активів». При придбанні інтелектуальної власності в обмін на корпоративні права, іiі вартість, вказану в засновнищыкому документі, також слід відобразити на рахунку 15 «Канітальні інвестиції».

Аудит ресурсозберігаючих інновацій спрямований на виявлення причин виникнення невідповідностей у системі ресурсо- і енергозбереження, процесах або продуктах/послугах нідприємства. Основна мета аудиту - зібрати об' єктивні свідоцтва, які дозволять виявити невідповідності в процесах, продуктах/послугах нідприємства; попередити і скорегувати дії, які можуть привести до невідповідностей.

Запропоновану модель обліку та аудиту ресурсозберігаючих інновацій доцільніше використовувати при стратегічному плануванні ресурсозберігаючих інновацій тих нідприємств, які входять до об'єднань або промислових груп, холдингів. Такий нідхід дасть нідприємству можливість визначити і оцінити невідповідність між обсягами ресурсів на іиновації та можливостями впровадження інноваційних 
ресурсозберігаючих технологій, а також чинники, що мають найбільший вплив на ресурсозберігаючі інновації нідприємств однієї фінансово-промислової групи або холдингу.

На думку автора, запропонована модель обліку і аудиту ресурсозберігаючих інновацій враховує поточні умови функціонування холдингу і складні умови роботи сучасних національних промислових нідприємств:

- обмежений доступ до виробничих ресурсів через високі ціни на них;

- необхідність постійного навчання персоналу усіх рівнів організації;

- необхідність економії ресурсів, які постійно дорожчають, і впровадження нових технічних та економічних рішень щодо ресурсозбереження;

- сувора конкуренція на національному та міжнародному ринках;

- нідвищення вимог до якості готової продукції;

- військовий конфлікт на Сході України, де знаходяться національні джерела вугілля, руди, вапняку та інші;

- затяжна економічна криза в світі та політична і економічна криза всередині країни.

Висновки. Впровадження запропонованого нідходу до організації обліку та аудиту ресурсозберігаючих інновацій може бути ефективно використано для нідвищення конкурентоспроможності національного промислового нідприємства, об'єднання або холдингу, особливо в умовах оновлення та перегляду економічних процесів в Україні. На основі комплексного підходу запропоновано удосконалення системи внутрішнього ресурсозбереження з обов'язковим врахуванням таких складових: технічне та технологічне покращення, ефективна кадрова складова, зниження матеріалоємності, енергозбереження та фінансово-економічні методи управління, що дозволить комплексно використовувати модель обліку та аудиту ресурсозберігаючих інновацій.

Перспективи подальших розвідок у цьому напрямі. Ресурсозбереження за рахунок зовнішніх факторів поступово стає більш складним та неефективним процесом. Саме з цієі причини необхідно вирішувати питання ресурсозбереження на промислових нідприємствах за рахунок внутрішніх резервів та ефективного використання виробничих ресурсів при впровадженні новітніх нідходів в управлінні: розроблення динамічного стратегічного розвитку нідприємства (холдингу, об'єднання) впровадження інноваційних технологічних рішень міжнародного рівня, раціональної організації праці, вдосконалення логістики та про()есійного нідходу до менеджменту і бухгалтерського обліку.

\section{Список використаних джерел}

1. Портер М. Конкурентное преимушество. Как достичь высокого результата и обеспечить его устойчивость. Пер. с англ. 2-е изд. М.: Альпина Бизнес Букс, 2006. $715 \mathrm{c}$.

2. Білопольський М. Г., Бессонова С. І., Бессонова Г. П. Проблеми обліку, аналізу та впровадження енергозберігаючих інновацій промислових нідприємств: моногр. Маріуполь: ДВНЗ “ПГТУ”, 2013. 102 с.

3. Економічна енциклопедія: У трьох томах. Т. 3 / Редкол.: С. В. Мочерний (відп. ред.) та ін. К.: Видавничий центр “Академія", 2002.952 с.

4. Логутова Т. Г., Полторацька О. В., Полторацыкий М. М. Проблеми ресурсозбереження металургійних нідприємств: теоретичні та практичні аспекти: моногр. Маріуполь: ДВНЗ “ПГТУ", 2016. 328 с.

5. Фоменко О. Р., Гречко А.В. Дослідження шляхів і резервів ресурсозбереження на нідприємстві // Акту альні проблеми економіки та управління. 2013. № 7 [Електронний ресурc]. URL: http://probl-economy.kpi.ua/pdf/2013-35.pdf

6. Національне положення (стандарт) бухгалтерського обліку в державному секторі 122 "Нематеріальні активи": затв. Наказом Міністерства (рінансів України від 12.10.2010 № 1202 [Електронний ресурс]. URL: http://zakon2.rada.gov.ua/laws/show/ z1018-10

7. Положення (стандарт) бухгалтерського обліку 27 “Необоротні активи, утримувані для продажу, та припинена діяльність": затв. Наказом Міністерства фінансів 
України від 07.11.2003 № 617 [Електронний ресурс]. URL: http://zakon2.rada.gov. ua/laws/show/z1054-03

8. Лаврененко В. В. Ціннісно-орієнтоване управління підприємством: ресурсгі аспекти // Вчені записки: функціональна економіка. 2012. № 14, Ч. 2. С. 139-144.

9. Кленіні О. В. Теорія, методологія та практика стратегічного консалтингу в системі управління інноваційним розвиток промислових нідприємств: моногр. Маріуполь: ДВНЗ “ПГТУ”, 2016.309 с.

И. Н. МАЙОРОВА,

доктор экономических ноук, профессор кафедры технологии международных перевозок и логистики, ГВУЗ «Приазовский государственныий технический университет»

\section{Учет и аудит ресурсосберегающих инноваций на современных промышленных предприятиях}

В статье представлен авторский взгляд на организацию учета и аудита ресурсосберегающих инновачий на промышленных предприятиях. Учет ресурсосберегаючих инноваций проводится как учет нематериальньх активов или объектов интеллектуальной собственности. Представлен авторский подход к организации аудита с учетом соответствия ресурсосберегающих инноваций тесту М. Портера из таких пунктов: изменения в технологиях позволяют снизить затраты, но при этом технологическое лидерство предприятия имеет стабильную позицию; благодаря ресурсосберегаючим изменениям изменяется и направление действий ключевых факторов затрат; ресурсосберегающие изменения способствуют улучиению структуры предприятия/холдинга.

Ключевые слова: ресурсосберегающие инновации, бухгалтерский учет, нематериальные активы, финансово-хозяйственная деятельность, затраты, полиуретановая пена, корреспонденция счетов.

I. M. MAYOROVA,

Dsc of Department for Technology of International Transportations and Logistics, Azov State Technical University

\section{Recording and Audit of Resource Saving Innovations at Modern Industrial Companies}

Resource saving and energy saving are essential components of "energy security" problem in all the countries, which raises the importance of analysis and revision of approaches to organization of recording and audit of resource saving innovations at industrial companies. The article 's objective is to study organization of recording and audit of resource saving technologies at industrial companies. A review' of resource saning purposes and methods is given.

For accounting purposes, innovations in resource saving are recorded now as intangible assets. Recording of resource saving innovations and technologies at industrial companies is confined to recording of transactions on creation or acquisition of patent rights objects and intellectual property objects. The author's approach to organization of audit by the conformity of resource saving innovations with $M$. Porter 's test is proposed. Data showing success story of a Ukrainian company manufacturing polyurethane foam sealant PENADO in the aerosol dispenser is used to confirm that Ukraine does have potentials to introduce and utilize resource saving technologies, including energy saving ones.

The proposed model for recording and audit of resource saving innovations should be used in strategic planning of resource saving innovations at the companies incorporated in industrial groups or holdings. Using this model, a company can reveal and assess the mismatch between amounts of resources that can be allocated in innovation and real capacities for introducing innovative resource saving technologies, and factors having the 
strongest impact on recourse saving innovations at companies incor porated in one financial and industrial group or holding. The proposed model accounts for the spectfic operative conditions in holdings and tough conditions for business operation of industrial companies in Ukraine.

Keywords: resource saving innovations, recording, intangible assets, financial and economic activities, expenditures, polyurethane foam sealant, correspondence of accounts.

\section{Поси.лання на статтю:}

Майорова I.М.Облік і аудит ресурсозберігаючих інновацій на сучасних промислових підприємствах // Науковий вісник Національної академії статистики, обліку та аудиту: зб. наук. пр. 2017. №3. С. 26-33. 